\title{
ҮйүрлүY жылкылардын бакубаттуулугун баалоо протоколунун концепциясы
}

\author{
Аскарбек Түлөбаев ${ }^{1 а *}$ \\ ${ }^{1}$ Кыргыз-Түрк «Манас» Университети, Ветеринария факультети, Бишкек, Кыргызстан
}

${ }^{a}$ https://orcid.org/0000-0003-1349-6511

*Корреспондент автор: askarbek.tulobayev@ manas.edu.kg

\begin{abstract}
АННО А ЦИ Я
Акыркы жылдарда дүйнөлүк илимий коомчулук тарабынан колдо асыралган айбандардын бакубаттуулук деңгээлин мүнөздөө жана баалоо үчүн бир нече багыттагы жана ар кандай форматтагы концепцияларды иштеп чыккан. Алардын ичинде жүрүш - турушка негизделген концепциялар айбандар өзүнүн табиятына жараша жашап жана түргө тиешелүү бардык иш - аракеттерди эч бир чектөөлөрсүз аткарууга мүмкүнчүлүк алышы керек дешет. Ал эми физиологиялык багытка негизделген концепциялар болсо, гомеостаз жана аллостаз түшүнүктөрүнө таянышып, организмдин ички чөйрөсүнүн динамикалык туруктуулугун башкы фактор катары кабыл алышат. Кыргыз Республикасында жылкылардын бакубаттуулугун баалоо протоколунун концепциясын иштеп чыгууда, жылкыларды үйүрдө багуунун климаттык жана технологиялык өзгөчө шарттарын эске алуу зарыл. Макаланын максаты - тоолуу жайыттардын шарттарында асыралган үйүрлүү жылкылардын бакубаттуулугун баалоо протоколунун концепциясын аныктоо болуп саналат. Изилдөөлөрдүн темасына ылайык илимий булактарды иликтөөлөр илимий китепканаларда жана интернет булактарында жүргүзүлдү. Жайыттардын шартында асыралган жылкылардын бакубаттуулук деңгээлин баалоо критерийлери же өлчөнүүчү көрсөткүчтөрү байкоонун түз жана кыйыр ыкмалары колдонулуп такталды. Алынган маалыматтар салыштырма ыкмасы колдонулуп анализденди. Изилдөөлөрдүн жыйынтыгында бакубаттуулуктун «беш эркиндик» принциптерине негизделген төмөндөгүдөй концепциясы аныкталды: 1) Кыргыз Республикасында үйүрлүY жылкылардын бакубаттуулук деңгээлин баалоодо AWIN (2015) протоколу негиз катары кабыл алынышы максатка ылайыктуу; 2) Жылкылар үйүрдүн курамында асыралгандыктан, бардык бээлер жана айгыр иликтөөгө алынышы зарыл; 3) Баалоо прициптери болуп төмөндөгүлөр кабыл алынды: I. Жакшы жайыт; II. Жакшы ден-соолук; III. Талаптагыдай жүрүш-туруш; 4) Жылкылардын бакубаттуулук деңгээлине баа берүүдө, 7 критерийдин алкагындагы ар бири 5 баллдык система менен баалануучу 20 көрсөткүчтүн колдонулушунун талапка ылайыктыгы ортого чыкты. Үйүрлүү жылкылардын бакубаттуулук баалоо протоколу негизинен жылкынын физиологиялык абалын жана жүрүш-турушун чагылдырган көрсөткүчтөрдөн туруп (85\%), жайыттын абалын, жылкыларды багуу жана тоюттандыруу шарттарын камтыган көрсөткүчтөр менен толукталып турат (15\%).
\end{abstract}

МАКАЛА

МААЛ Ы МА Т Ы

\section{The Concept of Welfare Assessment Protocol for Horses in Herd}

\section{A B S T R A C T}

The scientific community has developed several concepts to characterize and appreciate animal welfare. Behavioural approaches state that animals should live accordingly to their nature and should be able to perform all necessary behaviours without aversion. Physiological approaches based on the concepts of homeostasis and allostasis have been developed. In developing the concept of the welfare assessment protocol for horses in the Kyrgyz Republic, it is necessary to take into account the special climatic and technological conditions for keeping horses in herds. The purpose of this article is to define the concept of the protocol for assessing the welfare of herd horses bred in mountain pastures. Scientific review of sources in accordance with the research topic was conducted in scientific libraries and Internet sources. Criteria or indicators for assessing the level of well-being of horses bred in pasture conditions were clarified using direct and indirect methods of observation. The obtained data were analyzed using the comparative method. The study identified the following concept of well-being based on the principles of the "five freedoms": 1) It is expedient to adopt the AWIN (2015) protocol as a basis for assessing the level of welfare of horse-herd in the Kyrgyz Republic; 2) Since horses are bred in a herd, all mares and stallions should be examined; 3) The principles of evaluation are as follows: I. Good pasture; II. Good health; III. Proper behavior; 4) In assessing the level of well-being of horses, it was found appropriate to use 20 indicators, each of which is assessed on a 5-point scale within the framework of 7 criteria. The protocol for the assessment of the well-being of horse-herd consists mainly of indicators reflecting the physiological condition and behavior of the horse (85\%), supplemented by indicators covering the condition of pastures, conditions of breeding and feeding horses $(15 \%)$.

\section{Илимий макала \\ ЖиберҮҮ: 19.06.2021 \\ Кабыл алуу: 15.10.2021}

Ачкыч сөздөр: үйүрлүҮ жылкылар, айбандардын бакубаттуулугу, айбандардын бакубаттуулугун баалоо, бакубаттуулугун баалоо протоколу, жылкылардын бакубаттуулугун баалоо протоколунун концепциясы

To Cite: $\quad$ Түлөбаев А 2021. Үйүрлүү жылкылардын бакубаттуулугун баалоо протоколунун концепциясы. MJAVL Sciences. 11 (2) 131-137 


\section{КИРИШУУ}

Кыргыз Республикасынын өндүрүмдүу жылкы чарбасында кылымдардан бери колдонулуп келген жылкыларды үйүрдүн курамында асыроо технологиясынын мааниси жогорулоодо, анткени бул технология жылкыларды эт, бээ сүтү жана кымыз өндүрүү үчүн багуудагы эң арзан жана жөнөкөй ыкма болуп саналат.

Көчмөн тарыхтуу Борбордук Азия өлкөлөрүндө (Кыргыз Республикасы, Казахстан, Өзбекстан, Түркмөнстан, Тажикстан, Монголия), Россия Федерациясында (Хакас Республикасы, Башкыр Республикасы, Татар Республикасы, Алтай Республикасы, Тыва Республикасы, Саха (Якутия) Республикасы, Бурят Республикасы) жана Кытай Элдик Республикасында (Синцзян Уйгур автоном районунун Кызыл-Суу Кыргыз автоном округу, Ички Монголия ж.б.) жылкыларды үйүрдүн курамында асыроо технологиясы ар кандай өзгөчөлүктөрү менен колдонулуп келет.

Заманбап мал чарбасында индивидуумдун керектөөлөрүн камсыздоо деңгээлине жана дискомфорттук абалынын жоктугуна, ошондой эле «эркиндиктин беш эрежесине» негизделген Welfare-технологиялар колдонулууда. Welfare-технологияларда айбандардын бакубаттуулук деңгээли өзгөчө мааниге ээ болуп, айбандын физиологиялык жана биохимиялык көрсөткүчтөрүнө, жүрүш-турушуна, кунардуулук деңгээлине жана өндүрүмүнүн сапатына таянууда (Uoring 2007). Анткени деңгээли төмөн бакубаттуулуктагы мал генетикалык потенциалын толук даражада ишке ашыра албайт (Ivanov ж.б. 2012).

Айбандардын бакубаттуулук маселеси алгачкы жолу 1976-жылы Страсбургда кабыл алынган өндүрүмдүY айбандарды коргоо боюнча Европа конвенциясында чагылдырылган (ЕС 1976). Ал эми Евробиримдикте колдонуудагы жоболор айбандардын укуктарын жана керектөөлөрүн кыйшаюусуз аткарууну талап кылат. Бул талаптарды аткарбаган өндүрүүчүлөр «айыпталышып», эл аралык ыйгарым укуктуу органдар тарабынан экономикалык санкциялар салынат.

Айбандардын (малдын) бакубаттуулугу - татаал, көп кырдуу жана дисциплиналар аралык предмет болуп, илимий, этикалык, экономикалык, маданий, социалдык, диний жана саясий аспектерге ээ. Ошондуктан, айбандардын бакубаттуулугуна коомчулуктун кызыгуусу өсүп, OIE нин (Эл аралык эпизоотиялык бюро) артыкчылыктарынын бири болуп калды. Жыйынтыгында OIE нин айбандардын бакубаттуулугу боюнча глобалдык стратегиясы 2017-жылы анын бардык 182 өлкө-мүчөлөрү тарабынан кабыл алынган (OIE: Animal welfare 2021) (алардын ичинде Кыргыз Республикасы дагы бар).

Айбандардын бакубаттулук маселеси акыркы жылдарда илимий коомчулукта тынчсыздануунун жана аны баалоонун жалпы бир протоколдорун иштеп чыгуу аракеттеринин булагы болуп келгенине карабастан, тандалып алынган көрсөткүчтөрдүн негиздүүлүгү жана ишенимдүүлүгү сыяктуу көптөгөн маселелер дагы эле талкуу жаратып келет (Lesimple 2020).

Айбандардын бакубаттуулугун баалоонун үч типтеги өлчөөлөрү колдонулат: айбандарга негизделген (АВanimal based; жүрүш-туруш, жүндүн сапаты ж.б.), ресурстарга негизделген (RB-resource based; чөйрө, жашоо шарты ж.б.) жана башкарууга негизделген (MB-management based; башкаруу чечимдери, багуу жана тоюттандыруу шарттары ж.б.). Бул өлчөөлөрдүн комбинациясы айбандын бакубаттуулугунун төмөндөө белгилерин жана тобокелдиктерди эрте аныктоого мүмкүнчүлүк берет (Blokhuis ж.б. 2013; Visser ж.б. 2014; Viksten ж.б. 2016).

Ресурстук көрсөткүчтөргө (RB) негизделген протоколдор, айбандардын өзүнүн бакубаттуулук абалын баалабайт, конкреттүҮ ресурстар менен бакубаттуулуктун статусу ортосундагы байланыш ар дайым эле ачыкайкын эмес деп сынга учурап келет (Blokhuis ж.б. 2013; Viksten ж.б. 2016). Натыйжада акцент айбандарга негизделген көрсөткүчтөрдү (AB) көбүрөөк колдонууга жана алар менен байланышкан тобокелчиликтерди аныктоого бурулган (Sorensen ж.б. 2001; Viksten ж.б. 2016).

Жылкылардын бакубаттуулугун баалоо үчүн бир катар протоколдор иштелип чыкканы менен, өлчөөлөрдүн эл аралык стандарты жок. Мындай абал бакубаттуулукту баалоодо алынган жыйынтыктарды салыштырууну жана интерпретациялоону кыйындатууда.

Протоколдордун максаттары дагы айрмаланат, мисалы Швецияныкы мыйзамдуулуктун сакталышын камсыздоону расмий көзөмөл жүргүзүүнү көздөсө (Statens 2009), башкалары бакубаттуулуктун даана абалын баалоого жана жакшыртууга багытталган. Мисалы «Австралия бакубаттуулук протоколу» (АНІC 2011), кирешеси төмөн жана орто деңгээлдеги өлкөлөрдөгү жумушчу жылкылардын бакубаттуулугун баалоо үчүн SEBWAT (алгач WEWA) инструменти (Sommerville ж.б. 2018) жана кирешеси жогорку деңгээлдеги өлкөлөрдө беш жаштан жогорку курактагы, атканалардагы денникте жалгыз багылган жылкылар (Equus caballus) үчүн «Жылкылардын бакубаттуулугун баалоо AWIN протоколу» (AWIN 2015) ж.б. 
Тилекке каршы, олуттуу илимий-практикалык мааниге ээ болгон жылкылардын үйүрдүн курамында жайытта багуудагы бакубаттуулугу ушул күнгө чейин изилденген эмес.

Ачык маалыматтарды анализдөө, тоолуу жайыттардын шарттарында асыралган үйүрлүү жылкылардын бакубаттуулугун баалоо үчүн OIE нин сунуштары жана AWIN протоколу, адаптациялоодон кийин колдонууга ылайыктуу экендигин ачыктады.

Демек, Кыргыз Республикасында OIE нин сунуштарын жана AWIN протоколун колдонуу максатында, аларды жылкыларды үйүрдө багуунун өзгөчө географиялык, климаттык, технологиялык жана аба-ырайынын шарттарын эске алуу менен ыңгайлаштыруу (адаптация) жана шайкеш келтирүү зарылчылыгы бар.

Анткени дүйнөнүн көпчүлүк өлкөлөрүнөн айырмаланып, Кыргыз Республикасында жылкылар жылдын дээрлик көпчүлүк мезгилинде жүздөгөн жылдардан бери салттуу колдонулуп келген үйүрдө багуу технологиясы менен жайыттардын шарттарында өстүрүлөт (Turdubaev ж.б. 2014; Sydykbekov 2016; Tulobaev ж.б. 2018).

Илимий коомчулук айбандардын бакубаттуулугун мүнөздөө жана баалоо максатында бир нече концепция иштеп чыккан. Мисалы, жүрүш-турушка таянган концепция айбандардын табиятка шайкеш жашоосун колдосо (Rollin 1993), физиологияга таянган концепция гомеостазга жана аллостазга таянат (Sterling жана Eyer 1988; Broom жана Johnson 1993). Бирок, үйүрлүY жылкылардын бакубаттуулугун баалоо концепциясы аныкталган эмес.

\section{МАТЕРИАЛДАР ЖАНА МЕТОДДОР}

Изилдөөлөрдүн максаты болуп тоолуу жайыттардын шарттарында асыралган үйүрлүү жылкылардын бакубаттуулугун (ҮЖБ) баалоо протоколунун концепциясын аныктоо саналат.

Бул максатта Кыргыз-Түрк “Манас" университетинин жана “Мурас Башаты” коомдук фондунун шериктештигиндеги «Жайыттарда өстүрүлгөн жылкылардын бакубаттуулугун баалоо критерийлерин аныктоо» (KTMU-BAP-2020.FB.03, 2020) жана “Жылкы үйүрүнүн бакубаттуулугун баалоо протоколун иштеп чыгуу” KTMÜ-BAP-2021.FB.01 (2021) илимий долбоорлорунун алкактарында изилдөөлөр жүргүзүлгөн.

Изилдөөлөрдүн объектиси болуп Кыргыз Республикасынын жылкы чарбасындагы кеңири жайылган уюштуруу-укуктук формасы катары жылкыларды үйүрдүн курамында өстүргөн фермердик чарба эсептелингендиктен, кыргыз тукумундагы жылкылардын үйүрлөрү алынган.

Жылкылардын организмине таасир көрсөткөн негизги факторлор катары бийик тоолуу жайыт шарттарынын, сырткы жана ички дүүлүктүргүчтөрдүн көрсөткөн таасирлери каралат.

Жайыттардын шарттарында асыралган ҮЖБ баалоо протоколунун концепциясын түзүүдө жылкыларга тиешелүү болгон кыргыз элинин байыртадан бери колдонулуп келген салттуу билимдери жана терминдери дагы пайдаланылды (Aldashev 1989; Kyrgyz elinin uyutkuluu syrlary 2013).

Изилдөөлөрдүн темасына ылайык илимий булактарды иликтөөлөр илимий китепканаларда, илим-изилдөө мекемелеринде жана интернет булактарында жүргүзүлдү жана анализге алынды.

Байкоонун түз жана кыйыр ыкмалары колдонулуп, жайыттардын шартында асыралган жылкылардын бакубаттуулук деңгээлин баалоо критерийлери же өлчөнүүчү көрсөткүчтөрү такталды.

Алынган маалыматтар салыштырма ыкмасы колдонулуп иликтенди.

\section{ИЗИЛДӨӨЛӨРДУН ЖЫЙЫНТЫГЫ ЖАНА ТАЛКУУЛОО}

ҮЖБ деңгээлин баалоодо AWIN (2015) протоколу негиз катары кабыл алынып, Кыргыз Республикасында асыралган 522,6 миң баш жылкылардын (KRUSK 2021) дээрлик басымдуу көпчүлүгү 9,147 млн. гектарды түзгөн тоолуу жайыттарда өстүрүлөөрү эске алынды.

AWINдин (2015) сунушу боюнча фермадагы курагы 5 жаштан өйдө жылкылардын 13-14 башы баалоого алынышы керек болсо, Кыргыз Республикасында жылкылардын дээрлик көпчүлүгү тоолуу жайыт шарттарында жылкы үйүрүнүн курамында асыралгандыктан, үйүрдөгү бардык бээлер жана айгыр иликтөөгө алынышы зарыл деп табылды (үйүрдө бир айгыр жана орточо 30га чейин бээлер болушу мүмкүн). Үйүрдөгү кулун-тайлар жана кунандар баалоого алынбайт.

AWIN (2015) тарабынан сунушталган «Жакшы тоюттануу» жана «Жакшы турак-жай» бакубаттуулук принциптери Кыргыз Республикасында колдонулган жайыт технологияларына ылайык бириктирилип, «Жакшы жайыт» принциби катары аныкталды. 
Изилдөөлөрдүн алгачкы жыйынтыктарына илимий жана практикалык эксперттердин (окумуштуулардын, ветеринардык адистердин, жылкы асыроочулардын) жана рецензенттердин пикирлерин эске алып, тоолуу жайыттардын шарттарында жылкы үйүрүнүн курамында асыроодогу жылкылардын бакубаттуулук деңгээлине баа берүүдө, ар бири 5 баллдык система менен баалануучу 20 көрсөткүчтүн колдонулушу талапка ылайыктыгы ортого чыкты (1-табл.).

1-таблица. Жайыттардын шарттарында асыралган үйҮрлүҮ жылкылардын бакубаттуулук принциптери, критерийлери жана көрсөткүчтөрУ (А.3. Түлөбаев, 2021)

\begin{tabular}{|c|c|c|}
\hline \multicolumn{3}{|c|}{ Бакубаттуулук } \\
\hline принциптери & критерийлери & көрсөткүчтөру \\
\hline \multirow{3}{*}{$\begin{array}{l}\text { I. Жакшы } \\
\text { жайыт }\end{array}$} & 1. Жайыт комфорту & 1) Жайыттын оптималдуу жүгү (сыйымдуулугу). \\
\hline & 2. Ылайыктуу тоюттануу & 2) Дене абалы (кондиция) \\
\hline & 3. Суу менен камсыздалуу & 3) Суу булагы \\
\hline \multirow{11}{*}{$\begin{array}{l}\text { II. Жакшы } \\
\text { ден-соолук }\end{array}$} & \multirow{6}{*}{$\begin{array}{l}\text { 4. Травмалардын } \\
\text { (жаракаттануулардын) жана } \\
\text { ооруксунуунун жоктугу }\end{array}$} & 4) Тери жабуусунун өзгөрүүлөрү \\
\hline & & 5) Муундардын шишиги \\
\hline & & 6) Аксактык \\
\hline & & 7) Пролапсус \\
\hline & & 8) Жылкынын гримасы \\
\hline & & 9) Туяктардын абалы \\
\hline & \multirow{5}{*}{ 5. Ылаңдардын жоктугу } & 10) Жүндөрүнүн (түктөрүнүн) абалы \\
\hline & & 11) Табигый тешиктерден бөлүнүүлөр \\
\hline & & 12) Заңдын консистенциясы \\
\hline & & 13) Дем алуунун көйгөйлөрү \\
\hline & & 14) Жөтөл \\
\hline \multirow{6}{*}{$\begin{array}{c}\text { III. Талаптагыдай } \\
\text { жүрүш-туруш }\end{array}$} & 6. Социалдык жүрүш-туруштар & 15) Социалдык мамилелер \\
\hline & \multirow{5}{*}{ 7. Жеке жүрүш-туруштар } & 16) Стереотипиялар \\
\hline & & 17) Коркууга сыноолор \\
\hline & & 18) Жылкынын кишиге болгон мамилеси \\
\hline & & 19) Жүрүш-турушту сапаттык баалоо \\
\hline & & 20) Кыймылды чектөө \\
\hline
\end{tabular}

Жаңъь сунуштаган «Жакиы жайыт» принцииинин критерийлерине жана көрсөткүчтөрүнө төмөндөгүдөй толуктоолор жана өзгөртүүлөр киргизилди:

Критерийи - жайыт комфорту, көрсөткүчү - жайыттын оптималдуу жүгү (сыйымдуулугу). Эс алуу жана температуралык комфорт критерийлеринин, төшөнчү, денниктин өлчөмдөрү жана атканалар үчүн эсепке алынбайт көрсөткүчтөрүнүн ордуна кабыл алынган. Анткени жайыт шарттарында жылкылар денникте багылбайт жана төшөнчү колдонулбайт. Бирок башка үйүрлөр, башка түрдөгү мал менен жайыт колдонуу нормаларына ылайык, шарттуу мал башына эсептелген жайытты колдонуу мүмкүнчүлүгү жана жайыттын абалы эске алынды (Zhayyttardyn menedzhmenti 2017).

Жайыттын абалынан жана сапатынан малдын өсүп-өнүгүүсү дагы көз каранды. Жайыттын баалуулугун аныктоодо, ал жерде өскөн өсүмдүктөрдүн сапатынан тышкары, малдын коопсуздугуна, ден-соолугуна, эттенүүсүнө жана малчылардын жашоо-тиричилигине дагы таасир берүүчү көптөгөн жергиликтүү жагдайлар каралат. Баалоодо кыргыз элинин салттуу малчылыгында кылымдардан бери колдонулуп келген жайыттардын абалы боюнча абдан жакшы, жакшы, канааттандыраарлык, начар жана бузулган жайыт катары бөлүнүшү колдонууга алынды (Kөchmөnderdүn zhayyttary 2011).

Баалоодо аба-ырайынын абалы жана температуралык комфорт шарттары эске алынды. Анткени атканаларда атайын түзүлгөн микроклимат шарттарын ачык асман астында түзүү мүмкүн эмес. Ошондуктан жайытта асыралган жылкылар сырткы чөйрөнүн аба-ырайынын абалына көз каранды.

Критерийи - ылайыктуу тоюттануу, көрсөткүчү - дене абальл (кондиция). Өзгөрүүсүз кабыл алынды жана кыргыз элинин жылкынын эттүүлүгүн (семиздигин) баалоо боюнча салттуу билимдерин дагы колдонуу сунушталды.

Критерийи - суу менен камсыздалуу, көрсөткүчY - суу булагы. Узак суусоонун жоктугу критерийинин, суунун бардыгы көрсөткүчүнүн ордуна кабыл алынды. 
Критерийи - узак суусоонун жоктугу, көрсөткүчү - чака тести. Алынып салынды. Анткени жайытта жылкылар эркин багылгандыктан жана суу булагы жетишээрлик болгондуктан, сууну каалаган убакта ичишет, суусоо көйгөйү дээрлик жок.

Критерийи - кыймыл эркиндиги, көрсөткүчү - сейилдөөлөр. Алынып салынды. Анткени жылкылар жайыттардын шарттарында ар дайым бош абалында багылышкандыктан, тоюттануу, суу ичүү жана башка максаттарда эркин кыймылда болушат.

«Жакшы ден-соолук» принцибинин «Травмалардын (жаракаттануулардын) жоктугу» жана «Ооруксунуунун жана технологиялык ооруксунуулардын жоктугу» критерийлери «Травмалардын (жаракаттануулардын) жана ооруксунуунун жоктугу» критерийине бириктирилди. «Уурттардын жабыркашы» көрсөткүчү алынып салынды. Калган позициялар өзгөртүүсүз кабыл алынды.

«Уурттардын жабыркашы» көрсөткүчүнүн алынып салынышынын ачыктамасы: үйүрдө багылган жылкылар жумушчу максатта колдонулбагандыктан ноктолонбойт жана жүгөндөлбөйт. Ошондуктан уурттарынын жабыркашы сымал көйгөй жаралбайт.

«Ылаңдардын жоктугу» критерийи өзгөртүүсүз кабыл алынды.

«Талаптагыдай жүрүщ-турущ» принцибинин «Жүрүш-туруштун башка формалары», «Жылкынын кишиге болгон мамилеси» жана «Оң эмоциялык абал» критерийлери көрсөткүчтөрү менен кошо «Жеке жүрүштуруштар» критерийине бириктирилди. Анткени жылкы менен кишинин ортосундагы мамилелер, жылкынын эмоциялык абалы жана жылкыга тиешелүү жүрүш-туруштун башка формалары жылкыга тиешелүү жеке жүрүш-туруш болуп эсептелинет.

«Талаптагыдай жүрүш-туруш» принцибинин жаңы «Жеке жүрүш-туруштар» критерийине «Кыймылды чектөө» көрсөткүчү жаңы кабыл алынды. Анткени Кыргыз Республикасында жылкылардын дээрлик көпчүлүгү тоолуу жайыт шарттарында жылкы үйүрүнүн курамында ээн-эркин асыралгандыктан, жылкычылар тарабынан алардын кыймылын чектөө (тушоо, бөгөжүлөө, аркандоо ж.б.) жылкылардын бакубаттуулугуна тескери таасир берет деп эсептелиши жана бааланышы керек.

Жалпы жыйынтык “Баалоо жыйынтыгы” таблицасында көрсөтүлгөн системалар колдонулуп чыгарылат (2табл.). Демек, бакубаттуулукту баалоо процессинде жылкы 85-100 баллга ээ болсо, анын бакубаттуулук деңгээли «Эң жакшы», 75-84 балл - «Жакшы», 50-74 балл - «Орто» жана 49 баллдан төмөн болсо, жылкынын бакубаттуулук деңгээли «Жаман» деп бааланат.

2-таблица. Баалоо жыйынтызы

\begin{tabular}{|c|c|c|}
\hline 100 баллдык система & 5 баллдык система & Даража системасы \\
\hline $90-100$ & \multirow[b]{2}{*}{5} & \multirow{2}{*}{ Эң жакшы } \\
\hline $85-89$ & & \\
\hline $80-84$ & \multirow{2}{*}{4} & \multirow{2}{*}{ Жакшы } \\
\hline $75-79$ & & \\
\hline $65-74$ & \multirow{3}{*}{3} & \multirow{3}{*}{ Орто } \\
\hline $58-64$ & & \\
\hline $50-57$ & & \\
\hline 49 баллдан төмөн & 2 & Жаман \\
\hline
\end{tabular}

\section{кОРУТУНДУ}

Баалоо жүргүзүү бакубаттуулуктун «беш эркиндик» принциптерине негизделип, Кыргыз Республикасынын ветеринардык адисинин кесиптик этикалык Кодексинин жоболоруна ылайык аткарылышы шарт катары кабыл алынды (Кыргыз Республикасынын Ветеринардык Статуардык органынын (Ветпалата) I-республикалык конференциясында 27.07.2018-ж. кабыл алынган).

ҮЖБ деңгээлин баалоодо колдонулуучу көрсөткүчтөрдүн көпчүлүгү жылкыга контакт болбой эле байкоо ыкмасы колдонулуп алынышы зарыл.

ҮЖБ баалоо протоколунун концепциясы болуп төмөндөгүлөр аныкталды:

1) Кыргыз Республикасында ҮЖБ деңгээлин баалоодо AWIN (2015) протоколу негиз катары кабыл алынышы максатка ылайыктуу; 
2) Кыргыз Республикасында жылкылардын дээрлик көпчүлүгү тоолуу жайыт шарттарында жылкы үйүрүнүн курамында асыралгандыктан, үйүрдөгү бардык бээлер жана айгыр иликтөөгө алынышы зарыл;

3) Кыргыз Республикасында колдонулган жайыт технологияларына ылайык ҮЖБ деңгээлин баалоо прициптери болуп төмөндөгүлөр кабыл алынды: I. Жакшы жайыт; II. Жакшы ден-соолук; III. Талаптагыдай жүрүш-туруш.

4) ҮЖБ бакубаттуулук деңгээлине баа берүүдө, 7 критерийдин алкагындагы ар бири 5 баллдык система менен баалануучу 20 көрсөткүчтүн колдонулушунун талапка ылайыктыгы ортого чыкты (1-таблицаны кара).

ҮЖБ баалоо протоколунун концепциясы төмөндөгү өлчөө типтерине таянат:

$>$ ресурстарга жана башкарууга негизделген өлчөө тибине (R\&MB-resources and management based $15 \%)$ - «Жайыт комфорту», «Ылайыктуу тоюттануу» жана «Суу менен камсыздалуу»;

$>$ айбандардын физиологиясына негизделген өлчөө тибине (APhB-animal physiology based - 55\%) «Травмалардын (жаракаттануулардын) жана ооруксунуунун жоктугу» жана «Ылаңдардын жоктугу»;

$>$ айбандардын жүрүш-турушуна негизделген өлчөө тибине (ABB-animal behavior based - 30\%) «Социалдык жүрүш-туруштар» жана «Жеке жүрүш-туруштар».

Демек, ҮЖБ баалоо протоколу негизинен жылкынын физиологиялык абалын жана жүрүш-турушун чагылдырган көрсөткүчтөрдөн туруп (85\%), жайыттын абалын, жылкыларды багуу жана тоюттандыруу шарттарын камтыган көрсөткүчтөр менен толукталып турат (15\%).

\section{КЫЗЫКЧЫЛЫКТАРДЫН КАГЫЛЫШЫ}

Бул макалада кызыкчылыктардын кагылышы жок.

\section{АВТОРЛОРДУН САЛЫМЫ}

Бул макалада авторлор бирдей өлчөмдө салым кошушкан.

\section{ЫРААЗЫЧЫЛЫК}

Изилдөөлөр Кыргыз-Түрк “Манас" университети (КТМУ) тарабынан каржыланган жана "Мурас Башаты" коомдук фонду (МБКФ) көмөктөшкөн “Жылкы үйүрүнүн жайлоодогу жүрүш-турушун изилдөө (I этап)” 2018.FBE.04 (2018-2019), “Жайыттарда асыралган жылкылардын бакубаттуулугун баалоо критерийлерин аныктоо" KTMU-BAP-2020.FB.03 (2020) жана “Жылкы үйүрүнүн бакубаттуулугун баалоо протоколун иштеп чыгуу” КTMÜ-BAP-2021.FB.01 (2021) илимий долбоорлорунун алкактарында жүргүзүлгөн. Көрсөткөн көмөктөрү үчүн КТМУ жана МБКФ жетекчилигине ыраазычылык билдиребиз.

\section{КОЛДОНУЛГАН АДАБИЯТТАР}

AHIC: Australian Horse Industry Council 2011. Australian Horse Welfare Protocol. Available: http://www.horsecouncil.org.au/ahic/

Aldashev AA 1989. Mal charbasynyn zhana veterinariya terminderinin oruscha-kyrgyzcha sezdygy. Kyrgyzstan, Frunze (in Kyrgyz).

AWIN 2015. AWIN welfare assessment protocol for horses. DOI: 10.13130/AWIN_HORSES, 2015.

Blokhuis HJ, Miele M, Veissier I, Jones B 2013. Improving farm animal welfare: science and society working together: the welfare quality approach. Wageningen: Wageningen Academic Publishers, 232.

Broom DM, Johnson KG 1993. Stress and Animal Welfare, 1st ed.; Kluwer Academic Publishers: Dordrecht, The Netherlands, 211.

EC: European Convention for the Protection of Animals kept for Farming Purposes 1976. ETS No.087. Strasbourg, 10/03/1976. https://www.coe.int/en/web/conventions/full-list/-/conventions/treaty/087

Ivanov AA, Ksenofontova AA, Voynova OA 2012. Otsenka urovnya blagopoluchiya loshadey po fiziologogematologicheskim i etologicheskim pokazatelyam pri raznykh tekhnologiyakh soderzhaniya. Izvestiya TSKHA, 6: 159-164. (in Russian).

KRUSK (Kyrgyz Respublikasynyn uluttuk statistikalyk komiteti). Zhylky sany 2021. http://www.stat.kg/ru/ (kayryluu datasy: 10.06.2021). (in Kyrgyz). 
Kyrgyz elinin uyutkuluu syrlary 2013. Zhylky. Birinchi basylyshy. Bishkek, Kut Ber, 103. (in Kyrgyz).

Kechmenderdyn zhayyttary («Mal baguuchularga zhardam katary salttuu bilimderdin» seriyasy) 2011. TYz. K. Shapakov, RDF. Bishkek, Mara, 42. (in Kyrgyz).

Lesimple C 2020. Indicators of Horse Welfare: State-of-the-Art. Animals. 10(2): 294. https://doi.org/10.3390/ani10020294

OIE: Animal welfare 2021. https://www.oie.int/en/animal-welfare/animal-welfare-at-a-glance/ (кайрылуу датасы: 10.06.2021).

Rollin BE 1993. Animal welfare, science, and value. J. Agric. Environ. Ethic. 6: 44-50.

Sommerville R, Brown AF, Upjohn M 2018. A standardised equine-based welfare assessment tool used for six years in low and middle income countries. PLoS ONE 13(2): e0192354. https://doi.org/10.1371/journal.pone.0192354

Sorensen J, Sandoe P, Halberg N 2001. Animal welfare as one amongst several values to be considered at farm level: the idea of an ethical account for livestock farming. Acta Agr. Scand. A: An Suppl., 30: 1116.

Statens Jordbruksverk 2009. Vägledning för kontrollmyndigheter m.fl. Bilaga Checklista häst version 1.0. Statens Jordbruksverk, Sverige.

Sterling P, Eyer J 1988. Handbook of life stress, cognition and health. In Allostasis: A New Paradigm to Explain Arousal Pathology; Fisher S, Reason J, Eds.; Wiley: New York, NY, USA, 629-649.

Sydykbekov K 2016. Konevodstvo Kirgizstana i Perspektivı Razvitiya Plemennogo Konevodstva. Vestnik Kyrgyz national agrarian university after K.I. Skryabin. 3(39): 74-76. (in Russian).

Tulobaev A 2020. Defining criteria for assessing the welfare of horses bred in range conditions in Kyrgyzstan. Manas Journal of Agriculture Veterinary and Life Sciences. 10(2): 110-115. (in Turkish).

Tulobaev A, Niyazbekova Z, Askarbek G, Jorubaev S 2018. Specificities of Horse-Herd Keeping the Kyrgyz Horse. Vestnik Kyrgyz national agrarian university after K.I. Skryabin. 2(47): 183-187. (in Kyrgyz).

Turdubaev TJ, Imanov KE, Kashykeev KS 2014. Importance and current state of horse breeding in Kyrgyzstan. Vestnik Kyrgyz national agrarian university after K.I. Skryabin. Bishkek, 1 (30): 183-185. (in Russian).

Uoring DKH 2007. Povedeniye loshadi. SPb.: Gramota-Plyus, 153. (in Russian).

Viksten SM, Visser EK, Blokhuis HJ 2016. A comparative study of the application of two horse welfare assessment protocols. Acta Agriculturae Scandinavica, Section A - Animal Science. 66, 1: 56-65. http://dx.doi.org/10.1080/09064702.2016.1186726.

Visser EK, Neijenhuis F, de Graaf-Roelfsema E, Wesselink HGM, de Boer J, van Wijhe-Kiezebrink MC, van Reenen CG 2014. Risk factors associated with health disorders in sport and leisure horses in The Netherlands. Journal of Animal Science, 92, 844855.

Zhayyttardyn menedzhmenti: Fermerlerdin praktikalyk kendymderyn zhakshyrtuu boyuncha modul' 2017. TYzyYchyler: ZH. Kozhomuratova, U. Fisher-Zuykov, A. Isakov, S. Dzhumabayeva, A. Imanaliyev. Bishkek, 64. (in Kyrgyz). 